\title{
ANALYSIS OF BUSINESS STRATEGY DECISION MAKING IN INCREASING SALES OF WAROENG STEAK AND SHAKE BANDAR LAMPUNG
}

\author{
M. Oktaviannur ${ }^{1}$, Appin Purisky Redaputri ${ }^{2}$, Meyta Ayunara ${ }^{3}$, \\ Hendri Dunan ${ }^{4}$, Heylin Idelia Jayasinga ${ }^{5}$ \\ ${ }^{1}$ Administrative Science Study Program, Faculty of Social and Political Sciences, \\ Bandar Lampung University \\ 2,3,4,5 Management Study Program, Faculty of Economics and Business, \\ Bandar Lampung University \\ Email : appin@ubl.ac.id
}

\begin{abstract}
The high competition in the steak restaurant business in the city of Bandar Lampung has an impact on the management of Waroeng Steak and Shake so that the income received fluctuates every month, this makes researchers aim to find out what alternative strategies are appropriate for Waroeng Steak and Shake and which strategies are become a priority for Waroeng Steak and Shake, Gatot Subroto Bandar Lampung Branch. This researcher uses descriptive analysis method and uses the Soft System Methodology (SSM) method and the Annalitical hierarchy Process (AHP) method. The results of this study indicate that there are five sub-criteria internal factors and external factors there are three sub-criteria. The results of the decision making model using AHP show that Goal in Waroeng Steak and Shake increases sales with the first priority strategy by creating more modern service changes in, developing new types of food, promoting via billboards and promoting word of mouth.modern in, developing types of food new, promotions via billboards and word of mouth promotions.
\end{abstract}

Keywords: Business Strategy, Analytical Hierarchy Process (AHP), Decision Making

\section{Introduction}

Currently, companies face intense global market competition. The development of technology and business today is also very fast, this causes competition among culinary business actors to be even tighter. The company must be able to exert efforts to create a competitive advantage in the long run. One of the competitive advantages used is to be able to place its product or service in the minds of consumers with promotional power. The objectives of this study are: To find out what efforts Waroeng Steak has made shake Gatot Subroto Bandar Lampung. To find out what factors influence the success of Waroeng Steak and Shake in Bandar Lampung. To find out how the business strategy at Waroeng Steak and Shake Gatot Subroto Bandar Lampung. To find out which business strategies are the most prioritized is Waroeng Steak and Shake Gatot Subroto Bandar Lampung. 


\section{Literature Study}

Stepphen P. Robbins and Mary Coulter (1999: 172), a decision is a choice made from alternatives. The decision-making process is a series of stages consisting of eight steps which include identifying problems, choosing an alternative, and evaluating decisions.

According to Hubies and Najib (2014). "Strategic management is a set of managerial decisions and actions that determine organizational performance in the long run".

According to Rangkuti (2014) "This business strategy is also often called a functional strategy because this strategy is oriented towards the functions of management activities, such as marketing strategy, production strategy or functional strategy, distribution strategy, organizational strategy, and financial-related strategies. ".

Meanwhile, according to Allan Afuah (2004) in Hidayat (2015) states that: "Business is a set of activities carried out to create by developing and transforming various resources into goods or services desired by consumers".

According to Barusman (2018). The system has become increasingly complex, dynamic, interconnected and automated. With systems thinking, a holistic philosophy will be available with the ability to open critical system structures such as boundaries, inputs, outputs, spatial orientation, process structures, and complex interactions between systems and their environment. Understanding the structure of the system will make it easier for system engineers to design and produce systems that emphasize high capabilities for consumers (Parnell, 2008).

\section{Research Methodology}

This type of research is descriptive research. Literature research is carried out by studying the literature related to research on business strategy. Field research is collecting data or information by making direct observations to the place which is the object of the research.

The sampling technique is a sampling technique (Sugiono, 2010). There are various sampling techniques used in quantitative and qualitative research. The sampling technique in this study is nonprobability sampling using accidental sampling technique, which is sampling based on chance, that is, anyone who happens to meet the researcher can be used as a sample, if it is considered that someone who happens to be met is suitable as a data source (Sugiono, 2010).

Determination of sources is determined based on the involvement of the sources in the events of the sources' understanding of the events that occurred so that the information needed is very helpful for researchers. The sources in this study are as follows:

List of Resources:

1) Didik Winarno as the manager of the Waroeng Steak and Shake outlet at the Gatot Subroto Bandar Lampung branch.

2) Defrizal as an academic lecturer who understands business strategy.

3) Two employees and two customers 
According to Checkland and Poulter (2006) there are 7 Stages in Soft Systems Methodology, also known as SSM Classic. Currently, Soft Systems Methodology (SSM) is not only SSM classic whose implementation consists of seven stages according to the theory presented by Checkland. However, SSM itself is a methodology that is used to deal with unstructured problems, and continuously changes dynamically by using a variety of analysis tools or tools that can be used, so that it can find a balance between elements.

According to Yusuf S. Barusman, Appin Purisky Redaputri (2018). It can be concluded that SSM is a holistic approach in seeing the real and conceptual aspects of society. SSM sees every thing that happens as a system of human activities because a series of human activities can be called a system, where each activity relates to one another and forms bonds. The soft systems approach is considered a very productive methodology for studying every human activity that is involved. set in achieving certain goals.

Analysis of the Analytical Hierarchy Process (AHP) AHP is a decision support model developed by Thomas L. Saaty. This decision support model will describe a complex multifactor or multi-criteria problem into a hierarchy, according to Saaty (1993), hierarchy is defined as a representation of a complex problem in a multi-level structure where the first level is the goal, followed by the factor level, criteria, sub criteria, and so on down to the last level of alternatives. AHP's working principle is to simplify a complex and unstructured problem, as well as be strategic and dynamic through efforts to arrange a series of variables in a hierarchy (Eriyatno et al, 2007). A complex problem can be broken down into groups which are then arranged into a hierarchical form so that the problem will appear more structured and systematic.

\section{Analysis \& Discussion}

In this part, the researcher will discuss the condition of the Waroeng Steak and Shake company at the Gatot Subroto Bandar Lampung branch at this time, what efforts have been made by Waroeng Steak and Shake, Gatot Subroto Bandar Lampung Branch and how to model business strategy decision making using the Analytical Hierarchy method. Process (AHP). Based on the results of interviews or in-depth interviews, focus group discussions and filling out questionnaires with several sources, the following information was obtained. 


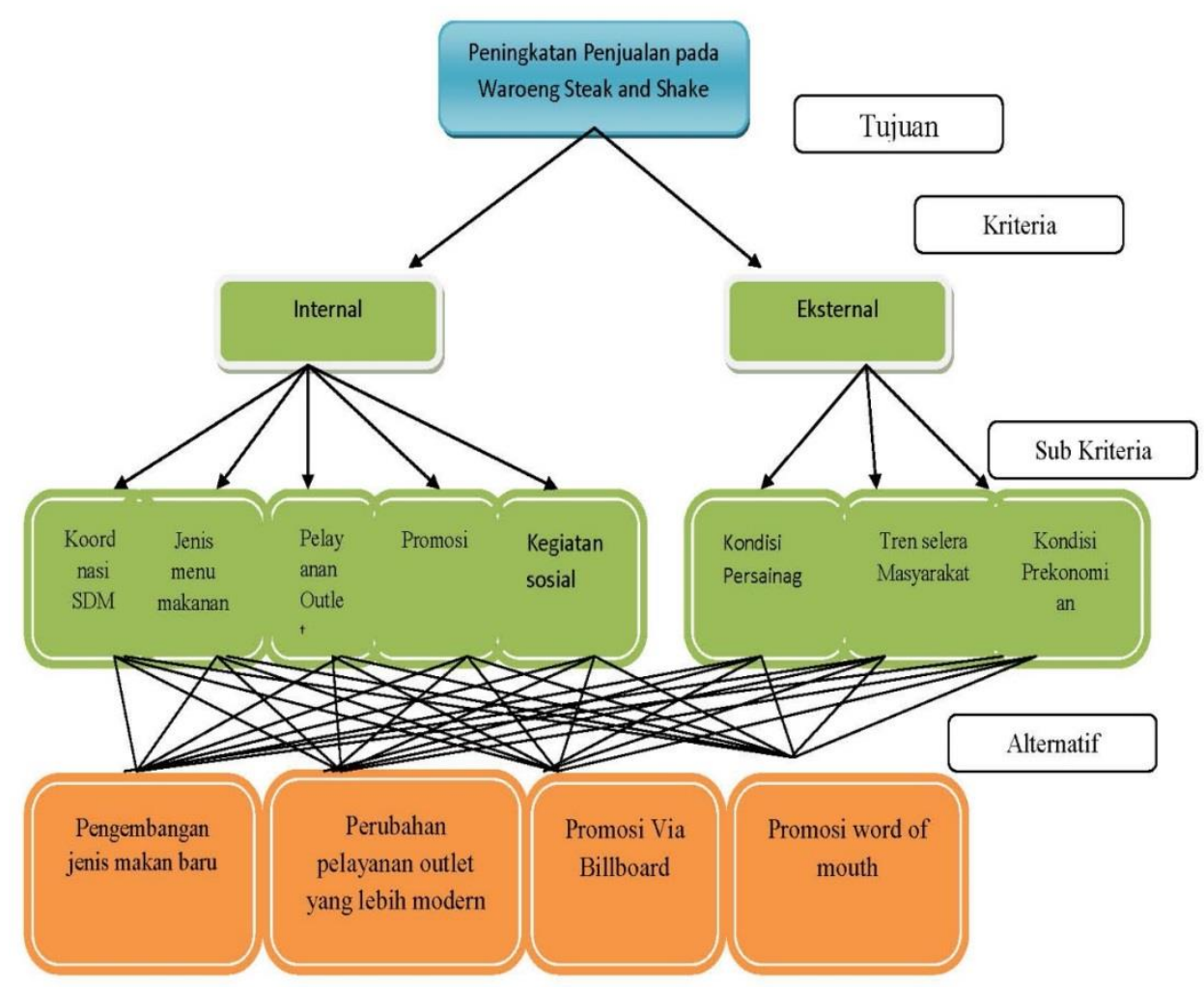

Figure 1. Research Hierarchy

From the hierarchy above, there are three (3) hierarchy levels, one (1) Goal (goal), namely Increasing the sales of Waroeng Steak and Shake at the Gatot Subroto Bandar Lampung Branch in a sustainable manner, two (2) criteria, namely internal and external factors, nine (8) sub-criteria, namely human resource coordination, type of food menu, service outlets, promotions, social activities, competitive conditions, trends in people's tastes, and economic conditions. billboards, and promotions via word of mouth. The following is a description of each of the existing criteria, sub-criteria and alternatives.

Of the six existing sources representing internal parties, the Waroeng Steak and Shake Outlet Manager, Gatot Subroto Bandar Lampung Branch, Staff, Employees, Customers, Academic Lecturers, a combination of decision-making modeling was made, the following results were obtained. 
International Journal of Economics, Business and Accounting Research (IJEBAR)

Peer Reviewed - International Journal

Vol-4, Issue-3, 2020 (IJEBAR)

E-ISSN: 2614-1280 P-ISSN 2622-4771

http://jurnal.stie-aas.ac.id/index.php/IJEBAR

Table 1. Combined Questionnaire Calculation

\begin{tabular}{|c|c|c|c|c|}
\hline GOAL & Level 1 & Level 2 & Alts & Prty \\
\hline & Percent Internal (L: ,347) & & & 34,6 \\
\hline & Internal (L: ,347) & Percent Koordinasi SDM (L: ,070) & & 2,4 \\
\hline & Internal $(\mathrm{L}:, 347)$ & Koordinasi SDM (L: ,070) & Pengembangan Jenis makanan baru & 0,002 \\
\hline & Internal (L: ,347) & Koordinasi SDM (L: , 070) & Perubahan Pelayanan outlet yang lebih modern & 0,012 \\
\hline & Internal (L: ,347) & Koordinasi SDM (L: , 070) & Promosi via Billboard & 0,002 \\
\hline & Internal (L: ,347) & Koordinasi SDM (L: , 070) & Promosi Word of mouth & 0,008 \\
\hline & Internal (L: ,347) & Percent Jenis Menu Makanan (L: ,507) & & 17,5 \\
\hline & Internal (L: ,347) & Jenis Menu Makanan (L: ,507) & Pengembangan Jenis makanan baru & 0,048 \\
\hline & Internal (L: ,347) & Jenis Menu Makanan (L: ,507) & Perubahan Pelayanan outlet yang lebih modern & 0,055 \\
\hline & Internal (L: ,347) & Jenis Menu Makanan (L: ,507) & Promosi via Billboard & 0,043 \\
\hline & Internal (L: ,347) & Jenis Menu Makanan (L: ,507) & Promosi Word of mouth & 0,029 \\
\hline & Internal (L: ,347) & Percent Pelayanan Outlet (L: ,118) & & 4,1 \\
\hline & Internal (L: ,347) & Pelayanan Outlet (L: ,118) & Pengembangan Jenis makanan baru & 0,004 \\
\hline & Internal (L: ,347) & Pelayanan Outlet $(\mathrm{L}:, 118)$ & Perubahan Pelayanan outlet yang lebih modern & 0,026 \\
\hline & Internal (L: ,347) & Pelayanan Outlet $(\mathrm{L}:, 118)$ & Promosi via Billboard & 0,003 \\
\hline & Internal (L: ,347) & Pelayanan Outlet $(\mathrm{L}:, 118)$ & Promosi Word of mouth & 0,008 \\
\hline & Internal (L: ,347) & Percent Promosi (L: ,229) & & 8 \\
\hline & Internal (L: ,347) & Promosi (L: ,229) & Pengembangan Jenis makanan baru & 0,033 \\
\hline & Internal (L: ,347) & Promosi (L: ,229) & Perubahan Pelayanan outlet yang lebih modern & 0,022 \\
\hline & Internal (L: ,347) & Promosi (L: ,229) & Promosi via Billboard & 0,009 \\
\hline & Internal (L: ,347) & Promosi (L: ,229) & Promosi Word of mouth & 0,016 \\
\hline & Internal (L: ,347) & Percent Kegiatan Sosial $(\mathrm{L:}, 076)$ & & 2,6 \\
\hline & Internal $(\mathrm{L}:, 347)$ & Kegiatan Sosial $(\mathrm{L}:, 076)$ & Pengembangan Jenis makanan baru & 0,007 \\
\hline & Internal (L: ,347) & Kegiatan Sosial (L: ,076) & Perubahan Pelayanan outlet yang lebih modern & 0,008 \\
\hline & Internal (L: ,347) & Kegiatan Sosial (L: ,076) & Promosi via Billboard & 0,003 \\
\hline & Internal (L: ,347) & Kegiatan Sosial (L: ,076) & Promosi Word of mouth & 0,008 \\
\hline & Percent Eksternal $(\mathrm{L:}, 653)$ & & & 65,4 \\
\hline & Eksternal (L: ,653) & Percent Kondisi Persaingan (L: ,737) & & 48,2 \\
\hline & Eksternal (L: ,653) & Kondisi Persaingan $(\mathrm{L}:, 737)$ & Pengembangan Jenis makanan baru & 0,117 \\
\hline & Eksternal (L: ,653) & Kondisi Persaingan $(\mathrm{L:}, 737)$ & Perubahan Pelayanan outlet yang lebih modern & 0,227 \\
\hline & Eksternal (L: ,653) & Kondisi Persaingan $(\mathrm{L:}, 737)$ & Promosi via Billboard & 0,043 \\
\hline & Eksternal (L: ,653) & Kondisi Persaingan $(\mathrm{L:}, 737)$ & Promosi Word of mouth & 0,095 \\
\hline & Eksternal (L: ,653) & Percent Tren Selera Masyarakat $(\mathrm{L}:, 108)$ & & 7,1 \\
\hline & Eksternal (L: ,653) & Tren Selera Masyarakat $(\mathrm{L}:, 108)$ & Pengembangan Jenis makanan baru & 0,026 \\
\hline & Eksternal (L: ,653) & Tren Selera Masyarakat $(\mathrm{L}:, 108)$ & Perubahan Pelayanan outlet yang lebih modern & 0,025 \\
\hline & Eksternal (L: ,653) & Tren Selera Masyarakat $(\mathrm{L:}, 108)$ & Promosi via Billboard & 0,007 \\
\hline & Eksternal (L: ,653) & Tren Selera Masyarakat $(\mathrm{L}:, 108)$ & Promosi Word of mouth & 0,013 \\
\hline & Eksternal (L: ,653) & Percent Kondisi Perekonomian (L: ,155) & & 10,2 \\
\hline & Eksternal (L: ,653) & Kondisi Perekonomian (L: , 155) & Pengembangan Jenis makanan baru & 0,012 \\
\hline & Eksternal (L: ,653) & Kondisi Perekonomian $(\mathrm{L}:, 155)$ & Perubahan Pelayanan outlet yang lebih modern & 0,069 \\
\hline & Eksternal (L: ,653) & Kondisi Perekonomian (L: , 155) & Promosi via Billboard & 0,013 \\
\hline & Eksternal (L: ,653) & Kondisi Perekonomian $(\mathrm{L}:, 155)$ & Promosi Word of mouth & 0,008 \\
\hline
\end{tabular}

In weighting this value by looking at the main objective of the research, the increase in sales then has criteria and has sub-criteria for each criterion, then the results of priority alternatives that are prioritized from the speakers will come out, namely as follows.

Table 2. Weight Calculation Results

\begin{tabular}{l|l}
\hline Alternative priorities for increasing sales & weight \\
\hline Development of new food types & 0,249 \\
\hline Changes to a more modern service outlet & 0,444 \\
\hline Promotion Via Bilboard & 0,123 \\
\hline Word of Mouth Promotion & 0,184 \\
\hline
\end{tabular}

Data sources were processed in 2020 
Based on the results of the data obtained from the analysis by researchers, the priority alternatives are prioritized by expert respondents in changing more modern outlet services with a value of (0.444), then developing new types of food with a value of $(0.249)$, then promotion via word of mouth with a value of $(0.184)$ and promotion via billboards $(0.184)$.

1) Changes to a more modern outlet service, the first priority alternative to achieve increased sales at Waroeng Steak and Shake, Gatot Subroto Bandar Lampung Branch. Where it will be seen first by consumers or in the minds of the community, so customers will feel comfortable with the change in a more modern outlet at Waroeg Steak and Shake, Gatot Subroto Bandar Lampung Branch. Outlet is a place that is categorized as a place that has certain rules and standards such as quality standards, menu quality standards, service standards, employee appearance standards etc.

2) Developing new alternative food types second priority to achieve increased sales at Waroeng Steak and Shake Gatot Subroto Bandar Lampung Branch. The development of new types of food is also very much needed by customers, both those who have just tried steak and shakes or those who frequently visit Waroeng Steak and Shake, Gatot Subroto Bandar Lampung Branch. To follow the trend of people's tastes, it is also necessary to develop new types of food. However, in the context of marketing and in the context of consumer behavior, innovation is associated with products or services that have never existed before in the market and are new in the sense that there are different things that are improvements or improvements from previous products that consumers have encountered.

3) Promotion of word of mouth, which is a communication process in the form of providing recommendations, either individually or in groups, for a product or service that aims to provide personal information. Promotion of the third priority alternative word of mouth to achieve increased sales at the Waroeng Steak and Shake Gatot Subroto Bandar Lampung Branch.

4) Promotion via billboards is a form of outdoor advertising promotion (outdoor advertising) and has a large size. In a real sense, a billboard is a poster with a size that is large enough and is placed high in a certain place that is busy passing by people. the fourth priority alternative to achieve increased sales at Waroeng Steak and Shake Gatot Subroto Bandar Lampung Branch.

\section{CONCLUSION}

Based on the research results obtained, this study aims to determine the model of decision making to increase sales at Waroeng Steak and Shake Gatot Subroto Bandar Lampung Branch. So based on the research results that the researchers can find, the factors that affect the success of a business strategy are:

1) Internal factors such as HR coordination, type of food menu, service outlets, promotions and social activities. 
2) External factors such as competitive conditions, public taste trends, and economic conditions.

Alternative Business Strategies at Waroeng Steak and Shake Gatot Subroto Bandar Lampung Branch, namely:

1) Development of new types of food

2) Changes to a more Modern Outlet Service

3) Promotion Via Billboard

4) Word of Mouth Promotion

Alternative Priority Strategies in Waroeng Steak and Shake at Gatot Subroto Bandar Lampung Branch, namely Changes to a More Modern Outlet Service.

Based on these conclusions, it is suggested:

1) Based on the conclusions and research results, Waroeng Steak and Shake Gatot Subroto Bandar Lampung Branch. We recommend that you focus on changing the service of a more modern outlet in order to achieve an increase in sales which will be seen first by consumers or in the minds of the community so that customers will feel comfortable with changes in more modern outlets. Example: In addition to using the existing system, customers come to make payments to the cashier by telling the table number, Tampa is waiting to go straight home, and the system can handle and can also criticize the service.

2) In addition to focusing on changes to more modern outlet services according to alternative priorities for further decision-making to achieve increased sales, we must also try to realize the development of new types of food, which are also very much needed by customers, both those who just try Steak and Shake or those who frequently visit Waroeng Steak and Shake, Gatot Subroto Bandar Lampung branch, and follow the trend of people's tastes, especially for Lampung itself. In developing new types of food, we can follow the trend of people's tastes, for example, such as the latest Abuba steak menu.

3) The Gatot Subroto Bandar Lampung branch of Waroeng Steak and Shake business can carry out the business strategy as described above to increase sales value.

4) Can conduct a survey after the improvement of a more modern outlet service change.

\section{REFERENCE}

Afuah, Allan.(2004) “Business Models : A Strategi Management Approach”. New York : Mc Graw-Hill.

Barusman, M.Y.S., (2018). Decision making model of electric power fulfillment in lampung province using soft system methodology.

Barusman, M.Y. S., Margono, M,.,\& Redaputri, A. P. (2019). Design of Excellent Service model on Department of Popolation and Civil Registation In City of Metro, Indonesia. Internasional jurnal of Research in Bussines and Social Science (2147-4478), 8(2), 52-60.

Checkland, P., Scholes, J. (1990). Soft Systems Methodology in Action.Chichester. 
International Journal of Economics, Business and Accounting Research (IJEBAR)

Peer Reviewed - International Journal

Vol-4, Issue-3, 2020 (IJEBAR)

E-ISSN: 2614-1280 P-ISSN 2622-4771

http://jurnal.stie-aas.ac.id/index.php/IJEBAR

Hubies, Musa dan Najib, Mukhamad. (2014). Manajemen Strategik dalam Pengembangan Daya Saing Organisasi. PT Elex Media Komputindo, Jakarta.

Jackson, M.C. (2003).Systems Thinking Creative Holism for Managers.University Of Hulk.

M. Yusuf S. Barusman Appin Purisky Redaputri (2018). - Decision making model of electric power fulfillment in lampung province using soft system methodology." Internasional Jounal of Energi Economics and Policy Universitas Bandar Lampung (Vol 8.Issue I.2018128) http://www.ecojournals.com/index.php/ijeep/article/view/5932

Rangkuti.(2014). Strategi Bisnis. PT. Gramedia Pustaka Utama. Jakarta.

Solihin. (2012). Pengertian strategi Bisnis. Di akses pada November 10,2019 dari http:library.binus.ac.id/eColls/eThesisdoc/BOL-S1-2016-00048\%20II.pdf.

Sugiyono. (2010). Metode Penelitian Kuantitatif Kualitatif \& RND. Bandung : Alfabeta. -(2011). Metode Penelitian Kuantitaif, Kualitatif dan R\&D. Jakarta:Alfabeta. 